\title{
The Application of Media Sibi and Rainbow Flag to Enhancement Locomotor Motion and Manipulative Motion of Deaf Disability Children on Basketball Material
}

\author{
Harries Tri Mada' ${ }^{1}$, Dwi Cahyo Kartiko' ${ }^{1}$, Gigih Siantoro ${ }^{1}$ \\ 1,2,3 Magister of Physical Education, Universitas Negeri Surabaya, Surabaya, Indonesia \\ harries.tr@gmail.com
}

\begin{abstract}
Everyone is entitled to education because education serves to improve the quality of a person's life. Education for deaf disability children, also needs to get focused of attention according to the limitations basic motor motion. The application of adaptive aplication learning media is used to improve motor skills of the disabled child's motor disability. The purpose of this research is to find out about: (1) the impact of application of media SIBI can help locomotor motion of deaf disability children, (2) the impact of media SIBI application to help manipulative motion of deaf disability children, (3) the impact of application of rainbow flag to help locomotor motion of deaf disability children, (4) the impact of the application of rainbow flags to help manipulative motion deaf disability children, (5) the magnitude of the increase in locomotor activity of deaf disability children using the application of media SIBI and rainbow flag, (6) the increase in manipulative activity of deaf disability children using the application of media SIBI and rainbow flags. This research is quantitative with quasi-experimental. The research design uses matching-only design, data analysis using Paired-Sampels T Test. The process of data collection is done with a pretest and posttest weight using the instrument of adapted motor skills, and validated by the expert to retrieve data locomotor motion and manipulative motion. The result of data analysis using SPSS version 20 on average data between pretest and posttest each group, namely: (a) Locomotor: media SIBI group increased $10,10 \%$, sig. $=0.003$ and the rainbow flag group increased $13.40 \%$, sig. $=0.001$. (b) Manipulative: media SIBI group increased by $10.10 \%$, sig. $=0.063$ and the rainbow flag group increased $13 \%$, sig. $=0.007$. Is increasing the influence of media SIBI and rainbow on locomotor motion $11,75 \%$ while in motion manipulative $11,55 \%$. The result of the the study, that the application of media SIBI to improve locomotor motion not for manipulatif motion behind rainbow flag to improve of locomotor motion and manipulative deaf disability children.
\end{abstract}

\author{
Keywords \\ media education; deaf \\ disability; locomotor \\ motion; manipulative
}

\section{Introduction}

Physical education is basically a process education physical activity is designed to improve the students health condition. But a child with special needs disabled athletes could not receive daily education normally given .Therefore need education services specifically .Education can be obtained a child with special needs disabled athletes formally through foundation or outside regular school ( $\mathrm{slb}$ ) .Each has a slb education curriculum in rehab, trains and educate which included physical education programs for children with special needs disabled athletes (physical education adaptive).

The base of the special education and specialized care also mentioned in act no 20 years 2003 the national education system the third article about function and national education targets and the fifth article paragraph $1,2,3$, and 4 about the same rights education irrespective of the physical condition, emotional, mental, intelligence and geography and in chapter 32 paragraph 1 and 2 , about special education and specialized care. In Regulation of 
the Minister of National Education number 34 years 2006 on guidance achievement students have the potential to intelligence or special talent and Regulation of the Minister of National Education number 70 years 2009 about education inclusive for students had. it has got the potential intelligence and or special talent.

Regarding the issue of the delivery of instruction or information children with special needs disabled athletes ( disability hearing impaired ) is required a proper media.Sibi stands for the gesture indonesian system. Sibi be a pleasant that helps communication fellow deaf or deaf communication with the broad.Its existence is order for a systematic set of the, hand, and various motion to symbolize vocabulary indonesian of video.The media sibi in learning physical education aimed to build cognitive students to have a skill motion picture who will be placed by teachers. When cognitive in students have embedded to help understanding will applied in a skill motion in the field, learning model physical education adaptive through the educational rainbow flags is a modification learning and developed by inserting element health condition that is using flags colored any color signified a certain movement. This media is these cues to attract students do a movement that instructed by teachers.

Discern exposure to the regulation can attributed by the presence of the existing problems in SDLB B pertiwi city mojokerto areas .One of the problems which there is less competence physical educator in the level of creativity in the development of innovative and kind of classroom, causing surfeit or fixed upon the introduction of duty of motion in a learning process .The matter often causes the weaknesses of understanding instruction and physical activity given. A method of learning a bad can affect their interests and their interest in participating in students learning .In order to get good feedback from students, phisycal education teachers adaptive must use a method of teaching who said because hearing a great deal to do the motivation of learning which he given to students.

\section{Research Methods}

The research was conducted at Primary School Extraordinary B Pertiwi, Mojokerto for 6 weeks with frequency 1 times a week. Participants of this study were 8 students of grade 6 . There were 2 groups with 4 participants in each group using matching system. Group 1 was given SIBI media as a learning medium for the material to be delivered and group 2 was given a rainbow flag as a learning medium so that the material could be delivered. This research uses quantitative research with Quasi Experimental Method. The design of the study only use the appropriate design, and data analysis using paired t-test dependent, while to know the magnitude of each treatment influence dilajutkan with . The process of collecting data was conducted by appraisal with a motor skills instrument adapted according to the needs of (Prof. Dr. Bandi Delphie M.A. S.E., 2009: 344-247) and validated to obtain data on locomor movement and manipulative motion, during pretest and posttest.

\section{Discussion}

Paired Samples Test test results dependent on SPSS 20 series program, as an effort to see which independent variables have a significant effect on the increase of dependent variable. The result from table 1 of SIBI group shows pair 3 value of Sig 2-tailed 0.063 means that there is no significant influence of SIBI media usage on manipulative motion of disabled children. 
Table 1. Paired Samples Test

\begin{tabular}{|c|c|c|c|c|c|c|c|c|}
\hline \multicolumn{9}{|c|}{ Paired Samples Test } \\
\hline & \multicolumn{5}{|c|}{ Paired Diferences } & \multirow[b]{3}{*}{$t$} & \multirow[b]{3}{*}{ of } & \multirow[b]{3}{*}{ Sig, (2-atilest) } \\
\hline & \multirow[b]{2}{*}{ Wean } & \multirow[b]{2}{*}{ Stat Deiation } & \multirow{2}{*}{$\begin{array}{l}\text { Std ETror } \\
\text { Mlean }\end{array}$} & \multicolumn{2}{|c|}{$\begin{array}{l}958 \text { Confidence interial of the } \\
\text { Difference }\end{array}$} & & & \\
\hline & & & & Lower & Upper & & & \\
\hline Pair1 POSTSBLL-PPESBbL & 2500 & 577 & .289 & 1.581 & 3.419 & 8.660 & 3 & 003 \\
\hline Pair2 POSTRFL-PRERFL & 3.250 & .500 & .250 & 2.54 & 4.046 & 13000 & 3 & .001 \\
\hline Pair3 POSTSIBII-PRESBII & 2500 & 1.732 & .866 & .256 & 5.256 & 2887 & 3 & .063 \\
\hline Pair4 POSTRFU-PRERFU & 3.250 & .957 & 479 & 1.727 & 4777 & 6.789 & 3 & .007 \\
\hline
\end{tabular}

Table 2. Descriptive Test Results of Basic Motion Capability Lokomotor SIBI Group

\begin{tabular}{|l|c|c|c|}
\hline \multicolumn{1}{|c|}{ Description } & $\begin{array}{c}\text { Pre Test } \\
\text { Locomotor }\end{array}$ & $\begin{array}{c}\text { Post Test } \\
\text { Locomotor }\end{array}$ & Different \\
\hline Minimum Value & 21 & 24 & 3 \\
\hline Maksimum Value & 29 & 31 & 3 \\
\hline Average & 24,75 & 27,25 & 2,5 \\
\hline $\begin{array}{l}\text { Standard } \\
\text { Deviation }\end{array}$ & 3,304 & 2,872 & 0,432 \\
\hline Variance & 10,917 & 8,250 & 2,667 \\
\hline \% Increase & $\frac{\text { Ma }}{\text { Mpre }} \times 100 \%$ & $\frac{2,5}{24,75} \times 100 \%=10,10 \%$ \\
\hline
\end{tabular}

Table 3. Descriptive Test Result of Basic Motion Capability Lokomotor Group Rainbow flag

\begin{tabular}{|l|c|c|c|}
\hline \multicolumn{1}{|c|}{ Description } & $\begin{array}{c}\text { Pre Test } \\
\text { Locomotor }\end{array}$ & $\begin{array}{c}\text { Post Test } \\
\text { Locomotor }\end{array}$ & Different \\
\hline Minimum Value & 24 & 27 & 3 \\
\hline Maksimum Value & 25 & 28 & 3 \\
\hline Average & 24,25 & 27,50 & 3,25 \\
\hline Standard Deviation & 0,500 & 0,577 & 0,077 \\
\hline Variance & 0,250 & 0,333 & 0,083 \\
\hline$\%$ Increase & $\frac{\text { Md }}{\text { Mpre }} \times 100 \%$ & $\frac{3,25}{24,25} \times 100 \%=13,40 \%$ \\
\hline
\end{tabular}

Tabel 4. Descriptive Result of Manipulative Basic Motion Capability Test of SIBI Group

\begin{tabular}{|l|c|c|c|}
\hline \multicolumn{1}{|c|}{ Description } & $\begin{array}{c}\text { Pre Test } \\
\text { Manipulative }\end{array}$ & $\begin{array}{c}\text { Post Test } \\
\text { Manipulative }\end{array}$ & Different \\
\hline Minimum Value & 22 & 22 & 0 \\
\hline Maksimum Value & 28 & 32 & 4 \\
\hline Average & 24,75 & 27,25 & 2,5 \\
\hline $\begin{array}{l}\text { Standard } \\
\text { Deviation }\end{array}$ & 3,202 & 4,573 & 1,371 \\
\hline Variance & 10,250 & 20,917 & 10,667 \\
\hline \% Increase & $\frac{M a}{\text { Mpre }} \times 100 \%$ & $\frac{2,5}{24,75} \times 100 \%=10,10 \%$ \\
\hline
\end{tabular}


Table 5. Descriptive Test Result of Manipulative Basic Motion Capability of Rainbow flag group

\begin{tabular}{|l|c|c|c|}
\hline \multicolumn{1}{|c|}{ Description } & $\begin{array}{c}\text { Pre Test } \\
\text { Manipulative }\end{array}$ & $\begin{array}{c}\text { Post Test } \\
\text { Manipulative }\end{array}$ & Different \\
\hline Minimum Value & 23 & 27 & 4 \\
\hline Maksimum Value & 27 & 30 & 2 \\
\hline Average & 25,00 & 28,25 & 3,25 \\
\hline $\begin{array}{l}\text { Standard } \\
\text { Deviation }\end{array}$ & 2,309 & 1,500 & 0,809 \\
\hline Variance & 5,333 & 2,250 & 3,083 \\
\hline \% Increase & $\frac{M a}{\text { Mpre }} \times 100 \%$ & $\frac{3,25}{25,00} \times 100 \%=13 \%$ \\
\hline
\end{tabular}

Table 2 shows that SIBI learning media with bolabasket material can improve locomotor base motion capability in sixth grade students of Primary School Extraordinary of $10.10 \%$. Table 3 shows that the provision of rainbow flags with bolabasket material can provide an increase in locomotor base motion capability in sixth grade students of Primary School Extraordinary at $13.40 \%$. Table 4 can be seen that giving SIBI learning media with bolabasket material can provide an increase in basic manipulative motion capability in sixth grade students of Primary School Extraordinary of $10.10 \%$. While table 5 can be seen giving rainbow flag with bolabasket material can give improvement of basic motion manipulative ability to sixth graders of Primary School Extraordinary of $13 \%$.

So, from the dependent test results between the dependent variable groups it can be concluded that the SIBI and rainbow flags provide improved locomotor motion and manipulative motion but no increase in SIBI media against manipulative motion.

\subsection{Increased the capacity locomotor motion basic through the application of the media SIBI on child disability hearing impaired the sixth grade in SDLB}

Based on the research there are significant influence in the field of the application of learning use SIBI media in locomotor basic motion .This statement with the results of testing in an empirical manner by means of t test paired t-test . As a capability of motion on the rest of the level of age to increase if it is conducted through a learning process. The results of the analysis different test the average between pretest and posttest indicated basic increase of motion through the application of locomotor media SIBI with a value of $p=0,003<\alpha=0.05$.

Based on analysis that has been made, shows that there is a capacity of locomotor motion to the disability hearing impaired the sixth grade primary school exceptional applied for learning use SIBI media in primary school remarkable B pertiwi mojokerto city.This was caused in line with the media and matter learning applied exactly with character students who have shortage of the senses hearing or disability hearing impaired that can support in reaching the purpose of learning. Where media sibi used to call attention to see the penyampaikan matter learning that the child is likely to perform a described in a media SIBI be repeated so has movement locomotor increased.

\subsection{Increased the capacity motion through the application of basic manipulative media sibi on child with a disability hearing the sixth grade in SDLB}

The mean difference of the result test analysis between pretest and posttest show that the data obtained in manipulative base motion $\mathrm{p}=0,063<\alpha=0.05$ 
Through the application of media sibi .The purpose of the application is to help a teacher to communicate with the students in order to increase learning basic motion locomotor and manipulative . Based on the results of the analysis that have been acquired, can show that there is not an increase in basic manipulative capability of motion with a disability hearing the sixth grade primary school learning use a remarkable resemblance to implementing media sibi in primary school remarkable b pertiwi city mojokerto areas. The result is based on less concerned students for learning matter in a media sibi so in practice students less whether perform a throw and get the ball. Media and matter learning applied exactly with character of students who have deficient in sense of hearing that can support in reaching the purpose of learning but there is a shortage of if the little regard there is no to increase motion manipulative skills.

\subsection{Increased the capacity motion locomotor through the application of basic learning use rainbow flag on child with a disability hearing the sixth grade in SDLB}

The research result obtained there are significant influence of the application of learning use rainbow flag in locomotor basic motion. This statement with the results of testing in an empirical manner by means of t test paired t-test . The results of the analysis different test the average between pretest and posttest show $p=0,001<\alpha=0.05$. So there is the increased through the application of basic motion locomotor learning use rainbow flag with a disability hearing the sixth grade primary school remarkable $b$ pertiwi city mojokerto areas. Because this was due to the rainbow flag is a flag colors, made in order to to communicate and attracting attention students. In every single color is having a meaning certain motion . Rainbow flag used to aid given the lectures learning for a hearing so that such a child with a disability are encouraged to perform a movement in a repetitive manner so that skill locomotor motion students increased.

\subsection{Increased the capacity basic motion manipulative through the application of learning use rainbow flag on child disability hearing impaired the sixth grade in SDLB}

Based on the results there are significant influence of the application of learning use rainbow flag on basic motion is manipulative .This statement with the results of testing in an empirical manner by means of $t$ test paired t-test.The results of the analysis different test the average between pretest and posttest show $\mathrm{p}=0,007<\alpha=0.05$. Based on the results of the analysis that have been acquired, can show that there is a basic manipulative increased capacity motion with a disability hearing the sixth grade primary school remarkable b pertiwi city mojokerto areas .

It occurred due to children interested in watching rainbow flags any color it has a motion specif to to convey matter learning or to do a movement and the encouraged to perform a movement described use rainbow the repeatedly so as to have capability of motion manipulative that rises. All that caused with the media and matter learning applied exactly with character students who have shortage of the senses audience that can support in reaching the purpose of learning.

\subsection{An increased of the movement locomotor basic through the application of learning use sibi rainbow media and flag}

Based on the results of data or the number of magnitudes the average increase of motion through the application of locomotor learning use media sibi as much as $10,10 \%$. Whereas the number of magnitudes average increase of motion locomotor through the 
application of learning rainbow the use as much as $13,40 \%$. So the average off the increase of motion through the application of the results of locomotor learning use sibi media and rainbow flag as much as $11,75 \%$. After the results of the analysis obtained this increase occurred because the media used will attract the interest of the child to pay attention to movement and memperaktekan and his word exactly the selection of media to the character of lack of students with disability hearing so that can support in the achievements of the purpose of learning the improvement of locomotor motion skills students.

\subsection{An increased of the capability of motion through the application of basic manipulative learning use sibi media and rainbow flag}

The results of the analysis of data obtained there is the amount of the average increase of motion through the application of manipulative learning use sibi media as much as $10,10 \%$. The average number of the increase of motion through the application of manipulative learning use rainbow flag by $13 \%$.So the average the size of the increase of motion through the application of the results of manipulative learning use sibi media and rainbow flag as much as $11,55 \%$. This was due to the matter with the media and of learning which applied right to the character of students will have to the senses district hearing so that can support the purpose of learning in the achievements of improving the skill motion manipulative students.

\section{Conclussion}

It can be concluded that sibi media can increase locomotor motion but not on motion manipulative while rainbow flag can increase locomotor motion and motion manipulative material through basketball .

\section{References}

Akram. B., et al. 2013. Scientific Concepts of Hearing and Deaf Students of grade VIII. Journal of Elementary education. Vol. 23, No. 1, Pp: 1-12.

Barboza. C. F. S., Campello, A. R., \& Castro, H. C. 2015. Sports, Physical Education, Olympic Games, and Brazil: The Deafness That Still Should Be Listened. Creative Education, 6, 1386-1390. http://dx.doi.org/10.4236/ce.2015.612138.

Basuki. S. 2011. Pembentukan Karakter Melalui Modifikasi Permainan Dalam Pembelajaran Pendidikan Jasmani. Jurnal ILARA, Vol 11, No 1, 63-69.

Bayraktar. I., et al. 2016. The Analysis of Certain Differences in Motor Skills of Sedentary Male Children in the 9-14 Age Grup Based on The Biological Maturity. Universal Journal of Educational Research 4(8): 1894-1902, DOI: 10.13189/ujer.2016.040820.

Bunawan. 1997. Komunikasi Total. Jakarta: Departemen Pendidikan dan Kebudayaan Direktorat Jenderal Pendidikan Tinggi Proyek Pendidikan Tenaga Akademik.

Chen. G. 2014. Influential Factors of Deaf Identity Development. Electronic Journal for Inclusive Education. Vol. 3, No. 2.

Delphie. 2009. Pembelajaran Anak Berkebutuhan Khusus. Sleman: Intan Sejati Klaten.

El-Zraigar. I. A. 2013. Assessing Special Needs of Students With Hearing Impairment in Jordan and Its Relation to Some Variables. Canadian Center of Science and Education. Vol. 6, No. 2, ISSN 1913-9020, E-ISSN 1913-9039. 
FIBA. 2005. Mini Basketball Rules. Switzerland.

Gallahue, D. L., \& John, C. O. 2006. Understanding Motor Development: Infants, Children, Adolescents, Adults. Boston: McGraw Hill. ISBN: 0072972963.

Hanief. Y. N., \& Sugito. 2015. Membentuk Gerak Dasar Pada Siswa Sekolah Dasar Melalui Permainan Tradisonal. Jurnal Sportif. Vol. 1, No. 1, 1-123.

Januarisca, E. L. 2009. Kemampuan Gerak Dasar Lokomotor dan Manipulatif Sebagai Hasil Pembelajaran Pendidikan Jasmani Olahraga dan Kesehatan di Sekolah. Surabaya: UNESA.

Kim. G. 2009. Embracing Diversity: Toolkit for Creating Inclusive, Learning-Friendly Environments Specialized Booklet 3 - Teaching Children with Disabilities in Inclusive Settings. Bangkok: UNESCO.

Maksum. A. 2012. Metodologi Penelitian. Surabaya: UNESA University Press.

Mulyani \& Tiswara, 2013. Pendidikan Jasmani Adaptif. Jakarta: Luxima Metro Media.

Meynert. M. J. 2014. Inclusive Education and Perceptions of Learning Facilitators of Children With Special Needs in a School in Sweden. International Journal of Special Education. Vol 29, No 2.

Mujianto. 2015. Pengembangan Model Penjas Adaptif melalui Permainan Rainbow Flag pada Siswa Tunarungu SMPLB. Semarang: UNNES.

Mutohir, TC. Gusril. 2004. Perkembangan Motorik pada Masa Anak-Anak. Bandung: CV. Alfabeta.

Nonis. K. P. \& Jernice. T. S. Y. 2014. The Gross Motor Skills of Children With Mild Learning Disabilities. International Journal of Special Education. Vol 29, No: 2.

Poedjiastoeti, S. \& Liliasari. 2010. Pembelajaran Kimia Berbantuan Multimedia untuk Siswa Tunarungu SMALB-B. Bandung: Universitas Pendidikan Indonesia.

Rofiandaru, 2013. Sistem Pembelajaran Bahasa Isyarat (SIBI) Menggunakan Metode Komunikasi Total untuk Penyandang Tunarungu di SLBN Semarang. Semarang: Universitas Dian Nuswantoro.

Santana. J. G. V., et al. 2015. Methodological Proposal For Elaboration Of Learning Materials In Sign Language In University Teaching. Spain: Universidad de Las Palmas de Gran Canaria. ISBN: 978-989-8533-40-1.

Setiyowati, N. 2015. Analisis Kebutuhan Perkembangan Fisik Motorik Halus Melalui Penerapan Kegiatan Kolase di RA Al Mutsnawiatul Islam Kelompok A Mlarak Ponorogo Tahun Ajaran 2015/2016. Surakarta: Universitas Sebelas Maret.

UNESA, 2015. Pedoman Penulisan Tesis dan Disertasi Program Pascasarjana. Surabaya: PPS Universitas Negeri Surabaya.

Vuljanic. A., et al. 2017. Sports-Anamnesis Profile Of Deaf Elite Athletes In Croatia. Croatia: International Scientific Comference on Kinesiology.

Zareian. E. \& Delavarian. F. 2014. Effect of Sport Stacking on Fine otor Proficiency of Children With Down Syndrome. International Journal of Sport Studies. Vol., 4 (8), 1010-1016, ISSN 2251-7502.

Zawi. K., Lian. D. K. C., \& Abdullah. R. T. 2014. Gross Motor Development of Malaysian Hearing Impaired Male Pre and Early School Children. Canadian Center of Science and Education Vol 7, No. 13, ISSN 1913-9020, E-ISSN 1913-9039. 